\title{
A argumentação e a configuração discursiva da certeza em A Casa dos Budas Ditosos
}

\author{
The argumentation and the discursive configuration of certainty in \\ A Casa dos Budas Ditosos
}

\section{Leonardo Alexander do Carmo Silva}

Université Sorbonne Nouvelle - Paris 3 - França

\begin{abstract}
Resumo: O romance A Casa dos Budas Ditosos é apresentado aos leitores como sendo a transcrição do depoimento oral de uma libertina sexagenária, identificada apenas pelas iniciais CLB. Naquela que é provavelmente a sua obra mais escandalosa e polêmica, João Ubaldo Ribeiro cria uma figura de autor/orador complexa e provocadora, que busca seduzir e exercer um poder através do discurso. A partir da constatação de que o depoimento tem uma forte dimensão argumentativa e uma finalidade persuasiva, buscamos estudar, neste artigo, como se caracteriza a retórica dessa libertina. Dessa forma, nos interessamos pelas estratégias argumentativas e recursos retóricos empregados pela narradora ao longo do romance. Para essa análise, utilizaremos como base teórica a Retórica de Aristóteles e obras contemporâneas como a de Perelman e Olbrechts-Tyteca, assim como trabalhos na área de semântica, como as de Bernard Pottier.
\end{abstract}

Palavras-chave: João Ubaldo Ribeiro. Literatura brasileira. Retórica. Persuasão. Argumentação.

\begin{abstract}
The novel A Casa dos Budas Ditosos is presented to readers as the transcript of the oral testimony of a libertine sexagenarian, identified only by the initials CLB. In what is probably his most outrageous and controversial work, João Ubaldo Ribeiro creates a complex and provocative author/orator's character, which seeks to seduce and exercise power through discourse. Because the testimony has a strong argumentative dimension and a persuasive purpose, we seek to study in this paper how is characterized the rhetoric of this libertine. Thus, we care for the argumentative strategies and rhetorical devices employed by the narrator throughout the novel. For this analysis, we will use as a theoretical basis Aristotle's Rhetoric and contemporary works such as Chaïm Perelman and Olbrechts-Tyteca's, as well as works on the semantics area, such as those of Bernard Pottier.
\end{abstract}

Keywords: João Ubaldo Ribeiro. Brazilian litterature. Rhetoric. Persuasion. Argumentation. 
O romance A Casa dos Budas Ditosos é apresentado aos leitores como sendo a transcrição do depoimento oral de uma libertina sexagenária, identificada apenas pelas iniciais CLB. Ao criar uma gênese ficcional do livro, o escritor João Ubaldo Ribeiro joga com as fronteiras entre ficção e realidade. O autor simula, dessa maneira, uma determinada situação de comunicação: uma mulher, supostamente real, busca, através do seu depoimento, supostamente verídico, transmitir uma certa mensagem ao mundo. Em seu depoimento, CLB não se contenta em relatar diversas aventuras sexuais, ela busca também agir sobre o leitor, ao defender certas práticas e ao tentar converter seu destinatário ao seu estilo de vida.

Esse depoimento caracteriza-se por seu caráter híbrido e não se reduz a um simples relato de vida ou a uma biografia ficcional. A narradora, identificada como autora, expressa sua opinião sobre uma grande diversidade de assuntos e, mais do que isso, faz uma defesa apaixonada de determinadas práticas e valores. O escritor baiano cria, portanto, uma figura de autor extremamente interessante, que é, ao mesmo tempo, uma grande contadora de histórias e uma hábil oradora. Através dessa autora ficcional, o escritor explora o poder do discurso e da palavra, já que sua personagem manipula certas verdades para conseguir persuadir o seu hipotético leitor.

Segundo a retórica clássica logos é o princípio racional ordenador do discurso. Para persuadir o seu interlocutor, não basta ao orador projetar uma imagem positiva de si mesmo e provocar certas emoções em seu auditório, ele deve também tornar explícito o seu raciocínio e mostrar o que parece ser a verdade. Para Aristóteles, os dois grandes tipos de argumentação lógica são o argumento dedutivo e o indutivo. Na Retórica, o Estagirita faz uma distinção entre as duas técnicas:

Demonstrar que algo é assim na base de muitos casos semelhantes é na dialética indução e na retórica exemplo; mas demonstrar que, de certas premissas, pode resultar uma proposição nova e diferente só porque elas são sempre ou quase sempre verdadeiras, a isso chama-se em dialética silogismo e entinema na retórica (ARISTÓTELES, 2005, p. 98).

A dedução, portanto, é o tipo de raciocínio no qual, geralmente, parte-se do geral para o específico. O orador apropria-se de uma lei tida como universal e procura mostrar como um caso específico se enquadra nessa categoria. O silogismo é a forma mais conhecida do raciocínio dedutivo, na qual a partir de duas premissas (proposições consideradas hipoteticamente como verdadeiras) chega-se invariavelmente a uma conclusão verdadeira, como no exemplo clássico: todos os homens são mortais; Sócrates era um homem; logo Sócrates era mortal. Já a indução é o tipo de raciocínio que vai do específico ao geral. A partir de um certo número de exemplos, muitas vezes baseados na observação ou na experiência, o orador procura fabricar uma lei geral ou universal. Para que o argumento dedutivo seja eficiente e persuasivo, as premissas devem ser verdadeiras. Para o argumento indutivo, faz-se necessário que os casos e exemplos apresentados sejam de fato representativos de uma realidade.

Ao longo de seu depoimento, a narradora de $A$ Casa dos Budas Ditosos utiliza tanto argumentos dedutivos, quanto indutivos para apoiar suas ideias. Encontra-se, por exemplo, a dedução quando ela fala de tópicos controversos, como o incesto: "Incesto era normal no Egito antigo, Juno era irmã e mulher de Júpiter, todo mundo comia todo mundo, é natural, artificial é a noção de incesto como um mal em si, não tem nada de intrinsecamente mau no incesto, antes muito pelo contrário, é uma força da Natureza, é natural!" (RIBEIRO, 1999, p. 101). A primeira premissa apresentada pela oradora é que o incesto era normal no Egito antigo (o que é contestado por alguns historiadores). A segunda premissa é que, na mitologia romana, Juno casou-se com o irmão Júpiter. Ela se apropria, portanto, de um mito. Uma terceira premissa está implícita em seu raciocínio: se uma prática é atestada desde os primórdios de civilizações antigas, é porque ela faz parte da natureza humana. A partir dessas proposições, ela chega à conclusão de que o incesto é natural. Como podemos ver, CLB 
se vale de premissas que são, em parte, contestáveis, para validar sua tese.

Constata-se que CLB constantemente força suas conclusões, ao apresentar premissas que não seriam unanimemente aceitas como verdadeiras, como no trecho a seguir: "Príapo foi substituído por São Gonçalo, no nosso politeísmo católico. Os católicos são politeístas" (RIBEIRO, 1999, p. 14). Poderíamos reduzir a declaração da autora a um silogismo: Príapo é um dos deuses gregos, que eram politeístas; os católicos substituíram Príapo por São Gonçalo; logo os católicos são politeístas. Ainda que, a seguir, em seu depoimento, ela desenvolva a sua tese, citando vários exemplos de deuses que teriam sido substituídos por santos católicos, o seu raciocínio torna-se problemático porque apresenta como proposição verdadeira (os católicos substituíram Príapo por São Gonçalo) algo que corresponde a uma análise pessoal. Também é problemático o pressuposto que está na base de seu raciocínio, o de que os santos seriam equivalentes a deuses na religião católica. Ainda que utilize a técnica da argumentação lógica, o que a narradora privilegia é o impacto da sua conclusão, deixando muitas vezes em segundo plano a validade de suas premissas.

O tipo de raciocínio que CLB utiliza ao falar do incesto pode ser encontrado quando ela defende a ideia de que todos deveriam experimentar cocaína:

\begin{abstract}
Acho, sim, que a pessoa deve experimentar boa cocaína. [...] Pergunte a um cientista nuclear o que é a realidade e ele vai gaguejar, se for honesto. Mas existe uma realidade percebida, e o ser humano não pode tolerá-la e aí altera a percepção. Desde que o homem é homem, ele procura isso por milhares de vias, as mais conhecidas sendo o álcool e as drogas em geral, naturais ou não. A música é isso, a música não é senão isso, o único intermediário é o ouvido, ela vai direto e afeta quem a ouve, nunca deixa de afetar, de uma maneira ou de outra. Então eu acho que se deve experimentar, é uma burrice não experimentar. Quem não usa nada, nem secretamente, é um perigoso louco que possivelmente mataria alguém (RIBEIRO, 1999, p. 105).
\end{abstract}

Nessa passagem, a narradora apresenta como premissas principais as seguintes asserções: o homem sempre buscou um outro tipo de realidade, diferente da realidade empírica; as drogas, como a música, são capazes de realizar esse desejo. De maneira implícita, ela deixa transparecer, mais uma vez, em sua argumentação, a ideia de que se algo é recorrente e faz parte da natureza humana, não deve ser reprimido. Logo, não há razão para não se experimentar cocaína ou qualquer outro tipo de droga. CLB apela constantemente para a noção de "natural" e de "normal". Para ela, o homem não deve fugir da sua essência.

CLB também recorre à argumentação dedutiva, quando defende a tese de que as pessoas devem ter relações sexuais com os amigos:

Não se oferece merda aos amigos, atentar nisso, os amigos são muito importantes. Então, livrar-se da merda, para poder oferecer a ambrosia, que está aí para quem quiser deixar de ser babaca e ver. Se se prestar atenção e se assumir a postura correta, o certo é comer os amigos, é absolutamente óbvio, chega a ser ridículo ter que dizer isso e apresentar como tese a ser discutida, não há nada a ser discutido, é elementar, lógico, curial. [...] Comer alguém deve ser um gesto de amizade e que complementa e aprofunda, não estraga essa amizade (RIBEIRO, 1999, p. 114).

Utilizando "merda" e "ambrosia" como metáforas, a oradora constrói um tipo de silogismo incompleto, ao afirmar que os amigos merecem sempre o melhor e ao deixar subentendido que o sexo é o melhor a se oferecer. Logo, ter relações sexuais com os amigos é a postura mais correta.

Além de argumentos dedutivos, CLB também utiliza a indução, ao procurar fabricar verdades universais a partir de casos específicos. Para isso, ela se baseia geralmente na sua própria experiência, na sua vivência e na observação, como ela deixa claro em algumas passagens do seu depoimento: "Isso pode parecer bobagem, mas não é. Evita muita aporrinhação posterior e é fruto da minha experiência" (RIBEIRO, 1999, p. 103); "O meu enunciado é fruto de muita vivência e processamento dessa vivência" (RIBEIRO, 1999, p. 139-140).

A narradora considera-se uma pessoa de exceção, perfeitamente em sintonia com seus desejos e com sua essência e, por essa razão, acredita ter a autoridade necessária para falar em nome de todos os indivíduos. Não é raro que a narradora utilize o próprio exemplo para validar uma ideia: 
Sou contra essa teoria segundo a qual os brasileiros têm belas bundas e alimentam uma fixação patológica por bundas somente por causa dos africanos. Isto é preconceito, as belas bundas da nossa gente vêm tanto da África quanto de Portugal, tanto assim que eu não tenho sangue africano nenhum, pelo menos que eu saiba, e sempre portei uma bunda acima de qualquer crítica, até hoje não envergonho (RIBEIRO, 1999, p. 43-44).

A partir da apreciação que ela tem de si mesma (evidentemente parcial), a oradora contesta um clichê e propõe uma nova verdade de cunho universal.

Como vimos anteriormente, para Aristóteles, o exemplo equivale, na retórica, à indução. Perelman e Olbrechts-Tyteca seguem o mesmo caminho ao afirmarem que o argumento pelo exemplo exige um acordo prévio sobre a possibilidade de uma generalização a partir de casos particulares (PERELMAN; OLBRECHTS-TYTECA, 1992, p. 472). Ao longo de seu depoimento, a oradora utiliza constantemente a argumentação pelo exemplo. Grande parte das histórias que CLB conta pode ser considerada como exemplos com finalidade argumentativa, já que tais casos corroboram a mensagem que ela quer transmitir: a da necessidade de todo indivíduo exercer plena e irrestritamente sua sexualidade.

Além da dedução e da indução, a narradora faz uso de outros instrumentos de persuasão, como o argumento de autoridade. No livro Traité de l'argumentation, Perelman e Olbrechts-Tyteca definem o argumento de autoridade como sendo aquele que utiliza os atos ou os julgamentos de uma pessoa ou de um grupo de pessoas como meio de prova em favor de uma tese. Eles acrescentam que o papel de uma citação é geralmente o de comprovar o que se diz através do peso de uma autoridade (PERELMAN; OLBRECHTS-TYTECA, 1992, p. 411). Em seu depoimento, a narradora de A Casa dos Budas Ditosos cita diversas pessoas públicas (em geral escritores e intelectuais) para conferir maior credibilidade e poder de persuasão a algumas das ideias que defende. Ao falar da importância de o homem ejacular na mulher, ela, cita, por exemplo, uma obra do escritor Isaac Bashevis Singer: "Uma vez li um conto de Isaac Bashevis Singer em que ele se referia ao pecado de Onan de maneira correta e afirmava que, quando o homem ejacula no chão, um diabinho é gerado" (RIBEIRO, 1999, p. 32). O conto do escritor americano corrobora, de uma maneira lúdica, o que a oradora defende diversas vezes durante o depoimento: que o esperma não deve ser "desperdiçado" e que o momento do gozo é sagrado.

Ao defender que a mulher exerce e sempre exerceu um domínio sobre o homem, CLB diz que compartilha a opinião do escritor inglês Robert Graves, o que também confere maior peso a sua tese que, por ser bastante controversa, só tem a se beneficiar com a referência a um autor consagrado: "Então o Bob Graves e eu temos sérias dúvidas sobre essa questão de a mulher ter sido sempre dominada" (RIBEIRO, 1999, p. 66). Ao falar da virgindade e da "honra feminina", a autora ficcional cita o autor italiano Pittigrilli, pseudônimo de Dino Segre: "Pittigrilli um escritor que hoje ninguém lê [..] dizia mais ou menos que, em vez de se preocuparem tanto com a integridade dessa honra, melhor fariam as mulheres italianas em lavá-la, com água mesmo e não com sangue, pelo menos uma vez por dia" (RIBEIRO, 1999, p. 40). Vale ressaltar que o argumento de autoridade não somente corrobora a visão da narradora, como também serve para exibir sua erudição, como quando a narradora cita Henry James:

Henry James escreveu não sei onde que ler um romance é olhar pelo buraco da fechadura. Este depoimento não é um romance, nem enredo tem - se bem que os do próprio Henry James também mal tivessem, pensando bem -, mas é olhar pelo buraco da fechadura (RIBEIRO, 1999, p. 130).

A citação de James serve para a narradora definir a natureza do seu depoimento: dar a ver o que geralmente está escondido e inacessível. Além de corroborar ideias, teses e opiniões, o argumento de autoridade pode também servir para justificar algumas atitudes da narradora. Quando CLB confessa que dormiu com diversos professores para poder passar no mestrado, ela utiliza uma suposta frase de um dos maiores ícones do cinema clássico hollywoodiano, Marilyn Monroe: "No feliz dizer de 
Marilyn Monroe, segundo eu li em alguma revista de fofoca, chupei muita pica, mas consegui muitos papéis" (RIBEIRO, 1999, p. 119). Novamente, encontra-se a ideia dos fins que justificam os meios.

A analogia pode ser, assim como o argumento de autoridade, um instrumento de persuasão eficiente. Uma relação de analogia é estabelecida quando através de uma comparação, identifica-se os traços comuns entre objetos ou realidades diferentes. Em uma passagem do seu depoimento, CLB defende a ideia de que é possível amar e se apaixonar por várias pessoas ao mesmo tempo e desenvolve a sua tese através de uma interessante analogia com a informática:

Hoje eu estou altamente informática. A superstição perniciosa generalizada é que é preciso deletar o anterior, para aceitar o novo. Que pobreza, que pobreza, que pobreza, que atraso! Se a memória aceita, se o perfil confere, se a senha foi dada, roda os dois programas ao mesmo tempo, roda os três, roda os vinte, porra! Minimiza um, roda embaixo o outro, exporta um arquivo pra lá, outro pra cá [...] Claro que a paixão nova, no primeiro momento, mobiliza muito o apaixonado, que tende a ficar cego para os outros arquivos e aí, na maior parte das vezes, o entulho burro começa a aporrinhar, o camarada foi treinado para não achar aquilo certo, tem que deletar o arquivo em uso, não sei o quê. A analogia informática continua certeira, é como um programa novo, um brinquedo novo. Mas depois a gente abre o arquivo mais antigo, é bom, reaviva, estimula, meu Deus, por que erigimos empecilhos absurdos e destrutivos da beleza da Criação, os arquivos podem conviver na maior paz; clica, ele abre, tudo pronto para o deleite de todos e o cumprimento cioso quão alegre da sina! O limite é a memória! $E$ quantos gugóis de bytes não temos na memória? Nunca vamos usar nem um zilionésimo, por mais que vivamos e abertos sejamos. (RIBEIRO, 1999, p. 151-152).

A analogia com a informática permite que CLB, de uma maneira didática, ilustre e defenda sua tese. No entanto, como em qualquer argumento por analogia, pode-se questionar a pertinência da comparação. Nesse caso, seria possível que o auditório contra-argumentasse que o ser humano não é totalmente comparável a um computador. O que na teoria da narradora funciona muito bem, pode revelarse na realidade pouco praticável, já que o homem é muito mais complexo que uma máquina e deve lidar com diversos sentimentos e emoções, muitas vezes contraditórios.

Outro recurso utilizado pela narradora em sua argumentação são as máximas. $\mathrm{Na}$ Retórica, Aristóteles já chamava a atenção para a força argumentativa desses enunciados, tidos como um meio legítimo de persuasão. Segundo o Estagirita, as máximas se caracterizam por se reportarem ao geral e não ao particular e por serem asserções simples, sem inferência, podendo ser comparadas às premissas ou às conclusões do entinema (tipo de silogismo retórico). Assim, quando uma máxima é justificada, transforma-se em uma argumentação mais complexa, como o silogismo. A máxima é um instrumento persuasivo importante devido à sua força perlocutória, própria da asserção, que desperta no auditório, geralmente, uma confiança no locutor de maneira espontânea. A máxima também corresponde a um tipo de silogismo incompleto e exige, portanto, a participação do auditório, que deve identificar ou acrescentar mentalmente sua justificação, que está subentendida. Por fim, a máxima parece cristalizar tudo o que diz respeito à experiência humana, aproximando-se do universal.

A narradora de A Casa dos Budas Ditosos manifesta um grande talento em produzir máximas que venham corroborar as ideias que veicula. É o que ocorre, por exemplo, quando defende que o homem deve se relacionar com ambos os sexos: "E um fodaço cheio de limitações não pode ser um fodaço" (RIBEIRO, 1999, p. 116). Ou quando faz a defesa de sua vida de exagero e luxúria: "Tudo em escala grandiosa assume grandiosidade. Creio firmemente que é o meu caso, não consigo vê-lo de outra forma, senão com orgulho" (RIBEIRO, 1999, p. 144). Muitas vezes as máximas da oradora assumem ares filosóficos: "A vida é uma mentira impenitente, renitente e resistente, e o único problema filosófico de fato é o suicídio" (p. 141-142); " [S]audosismo é uma espécie de masturbação sem verdadeiro prazer" (RIBEIRO, 1999, p. 55).

As máximas estão intimamente ligadas à expressão de uma verdade. Em seu discurso, a oradora exprime-se muitas vezes como se fosse a 
detentora da verdade, demonstrando uma grande convicção e assertividade em suas declarações. Em A Casa dos Budas Ditosos, a narradora alterna o relato de suas memórias sexuais com uma série de considerações sobre a sexualidade humana, que têm, às vezes, uma função didática, e, principalmente, uma finalidade persuasiva. A autora ficcional manifesta a intenção de convencer seu destinatário e agir sobre ele, demonstrando um grande comprometimento com aquilo que veicula. Colocando-se como uma grande autoridade no assunto do qual trata (sexo e sexualidade), ela se exprime como se fosse detentora de uma verdade ou de uma ciência: "E não estou fazendo nada demais, a não ser contar a verdade" (RIBEIRO, 1999, p. 132). Ainda que seu discurso seja atenuado pontualmente, principalmente ao final da narrativa, a postura da narradora é, geralmente, bastante autoritária. Ao falar em nome do bem coletivo e ao estabelecer o que é certo e errado a partir da sua visão da sexualidade humana e da sua própria experiência de vida, a narradora exclui todos aqueles que não apresentam comportamentos e pensamentos iguais aos seus.

É importante destacar que a atitude da narradora contraria um preceito essencial da retórica:

Remarquons d'ailleurs que vouloir convaincre quelqu'un implique toujours une certaine modestie de la part de celui qui argumente, ce qu'il dit ne constitue pas 'parole d'Évangile', il ne dispose pas de cette autorité qui fait que ce qu'il dit est indiscuté, et emporte immédiatement la conviction. II admet qu'il doit persuader, penser aux arguments qui peuvent agir sur son interlocuteur, se soucier de lui, s'intéresser à son état d'esprit (PERELMAN; OLBRECHTS-TYTECA, 1992, p. 21).

CLB faz justamente o contrário do que parece ser o ideal, veiculando sua opinião ou crença como um fato indiscutível. Ela atribui um estatuto de verdade a maioria de suas proposições.

O falante/enunciador pode expressar de diferentes maneiras o seu comprometimento com aquilo que enuncia. Em linguística, as modalidades estão intimamente relacionadas ao "eu", ao enunciador, pois caracterizam a maneira como ele expressa suas atitudes e opiniões. Em Sémantique Générale, Bernard Pottier afirma : "Tout propos est susceptible d'être modalisé par l'énonciateur. [...] Le
JE énonciateur est le maître des modalités (POTTIER, 1992, p. 76).”. Ao longo da narração, CLB interrompe diversas vezes o seu relato para inserir comentários, ensinamentos, dicas, reflexões ou constatações sobre o sexo e sobre a sexualidade humana. Nessas digressões, a modalidade epistêmica é privilegiada.

Pottier caracteriza a modalidade epistêmica como sendo endocêntrica, ou seja, orientada para a percepção, o saber e o crer do EU (POTTIER, 1992, p. 205). Essa modalidade está ligada ao domínio do cognitivo e a graus de conhecimento. Por meio dela, o falante marca seu maior ou menor comprometimento com a verdade daquilo que é dito. No romance, encontra-se uma grande recorrência de alguns modalizadores epistêmicos, que funcionam como marcadores de certeza, como locuções adverbiais ("com certeza", "sem dúvida"), advérbios ("certamente") e adjetivos ("claro" e "evidente"). Verifica-se também o uso abundante do sintagma verbal "tenho certeza" e suas variantes e do presente do indicativo associado a verdades universais.

O uso abundante desses modalizadores revela a maneira assertiva com que a narradora se expressa: "Ele era um homem completo e não sabia, certamente nunca viria a saber, se não me conhecesse" (RIBEIRO, 1999, p. 156). Nessa passagem, ela comenta sua influência sobre o jovem Paulo Henrique. Na segunda parte da proposição, uma assertiva negativa, a narradora apresenta uma asseveração forte. Para que o seu depoimento tenha maior credibilidade, a narradora se põe constantemente em situação de superioridade em relação aos outros personagens e ao próprio leitor. Ao exaltar o seu talento e vocação para o sexo, CLB coloca em evidência o fato de que é uma autoridade incontestável no assunto. É interessante observar o uso do advérbio "certamente" que, reforçado por "nunca", busca não abrir espaço para dúvidas. CLB veicula como sendo certo algo que, na realidade, não passa de uma especulação.

O mesmo tipo de comentário é feito quando a narradora relata detalhes de seu relacionamento amoroso com uma aeromoça e afirma ser a melhor 
parceira que a moça poderia encontrar na vida: "Os outros participantes certamente houve ou há, mas não podem ter sido melhores com ela na cama do que eu" (RIBEIRO, 1999, p. 138). Aqui, a narradora repete o uso do modalizador epistêmico "certamente", mas a segunda parte da proposição é marcada pela combinação da modalidade epistêmica e alética, já que ela assegura não ser possível que exista outro amante melhor do que ela. Novamente, trata-se de pura especulação que é, no entanto, veiculada como sendo um fato indiscutível.

A partir da sua posição de autoridade e levando sempre em conta sua vasta experiência, CLB faz uma série de considerações sobre assuntos tidos como tabus, sendo o mais controverso deles 0 incesto. Em um determinado momento de seu depoimento, ela interrompe o relato dos detalhes de seu relacionamento íntimo com o irmão Rodolfo para fazer a seguinte afirmação: "Tenho absoluta certeza de que o número de irmãos que transa com irmãs, tios e tias com sobrinhos e sobrinhas, pais com filhas e mães com filhos, ad infnitum, é muitíssimo maior do que a nossa hipocrisia admite, e não há razão por que deva ser de outra forma" (RIBEIRO, 1999, p. 101). Essa asseveração também não é baseada em nenhuma evidência concreta, a não ser na convicção/crença íntima da narradora e na sua experiência pessoal. O sintagma "ter certeza", reforçado pelo uso do adjetivo "absoluta", dá ao enunciado o peso de um argumento de autoridade. A utilização do presente do indicativo, de verdade universal, tem valor epistêmico. A proposição se divide em duas partes: primeiramente, a narradora propõe que a prática do incesto é mais comum do que se imagina para, em seguida, defender que ela é válida. Ou seja, a narradora tenta desmitificar um tabu.

Antes de tratar o tópico do incesto de maneira mais aprofundada, a narradora já havia anunciado sua posição a respeito do assunto: "Evidente que é natural, a maior parte das pessoas passa pelo menos uma fase de tesão no irmão ou na irmã, só que a reprime em recalques medonhos" (RIBEIRO, 1999, p. 53). Novamente a oradora baseia-se em sua experiência pessoal para ditar o que é natural ou válido como prática sexual. É importante chamar a atenção para o uso de "evidente", adjetivo com função predicativa, como modalizador epistêmico. Nesse trecho, a narradora evita uma generalização total, utilizando o sintagma nominal "a maior parte das pessoas".

Outro tema caro à narradora-autora é o da sexualidade feminina. No romance, CLB interrompe o relato de suas aventuras sexuais com o irmão para introduzir uma longa digressão sobre o que as mulheres apreciam ou não no sexo. Adotando novamente uma posição de autoridade no assunto, a narradora compartilha com o seu narratário, algumas "verdades" a respeito das preferências femininas:

Escreva-se: a) nenhuma mulher gosta de pau mole; b) excetuadas dimensões aberrantes e as outras variáveis sendo equivalentes, o pau maior e mais vistoso é preferido. Evidente que o principal, principalíssimo, é quem é o proprietário do pau. Mas aí, se é pequeno, a mulher apenas deixa para lá, embora preferisse que fosse maiorzinho; é mais satisfatório, por alguma, ou várias, razões. Esta é que é a realidade, o resto, repito, é onda e pensamento voluntarista (RIBEIRO, 1999, p. 99).

Observa-se, nesse trecho, o caráter normativo e prescritivo da proposição da narradora, que adota uma postura quase didática, através da enumeração e do imperativo "escreva-se", que indica que o que vem a seguir é certo e comprovado. Constata-se também o uso abundante do presente do indicativo e do adjetivo "evidente", marcas de certeza. A narradora se coloca como porta-voz ou representante do gênero feminino e fala em nome das mulheres. Além de se comprometer fortemente com as ideias que veicula, a narradora não dá crédito a qualquer argumento contrário ao seu, ao assegurar que o que ela afirma é a verdade única. A repetição do verbo "ser" e a utilização do verbo "repito" revelam a necessidade de se reforçar enfaticamente a informação em uma tentativa de convencer o destinatário.

A repetição é, aliás, um dos procedimentos de persuasão mais utilizados por CLB que, ao longo de seu depoimento, insiste em determinados tópicos. Por exemplo, pouco antes do trecho acima apresentado, 
ela já havia tratado a questão do tamanho do órgão sexual masculino: "Ninguém me venha com essa história, muito citada por aí e até sacramentada em pesquisas pseudocientíficas, de que pau pequeno não faz diferença, claro que faz, um pau bem dimensionado preenche apropriadamente a mulher e é um visual estimulante e excitante, nada desse negócio de pau pequeno" (RIBEIRO, 1999, p. 98). A narradora inicia sua proposição recusando uma provável contra-argumentação à sua opinião, em uma postura reativa. Logo em seguida ela reitera, utilizando novamente um modalizador epistêmico, "claro", sua opinião que, segundo ela, condiz com a realidade dos fatos.

O depoimento da narradora-autora de $A$ Casa dos Budas Ditosos se baseia, em grande parte, em generalizações. Ao longo do romance, ela faz uma quantidade considerável de asseverações generalizadoras, que muitas vezes têm uma finalidade humorística, já que ela veicula certas ideias ou opiniões, muitas vezes discutíveis, controversas ou simplesmente absurdas, como sendo verdades absolutas ou leis da natureza. Tal prática, associada ao seu falar sem pudores, contribui para a criação de uma imagem cômica da narradora. Veem-se, portanto, privilegiadas, não somente a modalidade epistêmica, mas também a modalidade alética, aquela que diz respeito à verdade necessária ou contingente das proposições.

A narradora faz uso recorrente de pronomes adjetivos indefinidos, como "todo" e "nenhum", e do pronome substantivo indefinido "ninguém". Muitas das diversas frases que apresentam generalizações através desses pronomes têm a clara intenção de chocar o destinatário pelo seu caráter politicamente incorreto, inusitado, preconceituoso e/ou inverossímil. Vejamos alguns exemplos:

1 - "Meu avô - o outro avô, o alemão, um prussiano insuportável, nazista de nascença como todo alemão, embora tenha morrido se proclamando antinazista, como também todo alemão" (RIBEIRO, 1999, p. 20);
2 - “[...] embora fosse machíssimo como todo português, inclusive os veados" (RIBEIRO, 1999, p. 42);

3 - "E olhe que eu sou baiana e, como todo baiano, criada com preconceito contra carioca. Baiano tem preconceito contra todo mundo, aliás, quem quiser que pense que entra mesmo em casa de baiano, porque não entra" (RIBEIRO, 1999, p. 126).

A narradora reforça certos estereótipos, ao associar a nacionalidade alemã ao nazismo (em 1) e a portuguesa ao machismo (em 2). Em 3, ela aborda a questão do preconceito através de outra generalização, ao reforçar a ideia de uma rivalidade entre baianos e cariocas, e, logo depois, ela desconstrói a imagem que se tem dos baianos de pessoas receptivas e calorosas.

Essas declarações, pequenas digressões feitas por CLB ao longo da narração, nos permitem verificar o uso indiscriminado que ela faz de generalizações e a maneira com a qual ela se apropria de estereótipos (para reforçá-los ou para contestá-los). Em A Casa dos Budas Ditosos, a maioria das generalizações relaciona-se com o sexo e a sexualidade.

O tema da bissexualidade, por exemplo, é abordado diversas vezes ao longo do romance, sempre sob a forma de generalizações, como podemos ver através dos seguintes exemplos:

1- "Todo homem é veado, em maior ou menor grau, e toda mulher é lésbica, em maior ou menor grau. Ninguém é alguma coisa de forma absoluta, não há hipótese. Case histories uma atrás da outra, devo ter uma das maiores coleções do mundo, somente contando com meu tempo com Fernando e com Antônia" (RIBEIRO, 1999, p. 133);

2- "Heterossexualismo exclusivo, limitação. Homossexualismo exclusivo, limitação. Bissexualismo, normal, tanto assim que na infância desperta em todos e todas, sem exceção" (RIBEIRO, 1999, p. 159);

3- "Todo homem que disser que nunca, na vida toda, sentiu nenhum tesão por absolutamente nenhum outro homem, até um belo transexual ou um efebo, mas nenhum mesmo, ou está mentindo ou se enganando" (RIBEIRO, 1999, p. 116).

Constata-se, primeiramente, que a narradora repete a mesma ideia diversas vezes, de diferentes maneiras, o que pode ser considerado como uma 
estratégia de persuasão. Os trechos acima mostram novamente o uso abundante de marcas de generalização ("todo", "nenhum" e "ninguém") e do presente do indicativo de verdade universal. Verificase também que a narradora recusa qualquer tipo de atenuação ou contra-argumento, através da utilização de algumas expressões como "não há hipótese" (trecho 1) e "sem exceção" (trecho 2).

Em outra passagem, após narrar suas aventuras sexuais com o marido Fernando e outros parceiros de ambos os sexos, em orgias, ménage-àtrois e troca de casais, a narradora faz uma longa exposição sobre a bissexualidade, que é, segundo ela, um atributo de todo ser humano:

\begin{abstract}
Excetuando casos graves de doença mental, todas as mulheres gostam de mulher também, em graus variados ou até especializados, do mesmo jeito que todo homem gosta de homem, faz parte da constituição de nós todos, ninguém nasceu com papel sexual rígido, todo mundo é tudo em maior ou menor grau, o resto é medo de fantasmas ridículos e absurdos, que nunca se sustentaram nas suas pernocas de névoa. (RIBEIRO, 1999, p. 117).
\end{abstract}

Constata-se, primeiramente, a repetição do pronome adjetivo indefinido "todo" (e suas variações): são 4 ocorrências em uma única frase. Verifica-se também o uso dos pronomes substantivos indefinidos "ninguém" e "tudo" e do advérbio de negação "nunca". Todos esses elementos, combinados com o uso do presente do indicativo (de verdade universal), realçam não somente o tom extremamente assertivo da narradora, mas também o fato de que a série de generalizações que ela enuncia toma forma de leis da natureza. O discurso da narradora se baseia nas noções de normal e natural e, através da generalização, ela sistematiza o que é normal/natural (próprio à natureza do ser humano) e o que é anormal. Para corroborar sua tese de que a atração por ambos os sexos é natural, ela utiliza argumentos de ordem biológica: "faz parte da constituição de nós todos, ninguém nasceu com papel sexual rígido".

Além de estabelecer o que é normal, CLB estipula o que é anormal, já que, segundo ela, somente aqueles que sofrem de severa doença mental, escapam da regra. Ainda que o propósito da narradora não seja totalmente absurdo na teoria, ao contrário dos exemplos apresentados anteriormente, a radicalidade com que ela se expressa e a falta de distanciamento crítico (o uso do adjetivo "ridículos", que denota juízo de valor, por exemplo) revelam que se trata de uma opinião à margem do discurso científico ou de qualquer discurso oficial. A narradora cria para si mesma a imagem de uma mulher que fala o que ninguém mais tem coragem de dizer, sem filtros e sem preocupações com o que os outros vão pensar (talvez por saber que morrerá em breve e também pelo fato de que sua identidade será protegida).

Ao final do romance, CLB faz uma série de considerações de cunho didático e educativo, já que ela busca esclarecer o seu leitor sobre algumas verdades relativas ao sexo. Além da questão da bissexualidade, ela volta a falar do desejo feminino:

Toda mulher que não dá a bunda sente vontade de também dar a bunda nessas horas, toda mulher que nunca deixou gozarem em sua boca sente vontade de chupar um pau até que ele esguiche forte em sua boca, toda mulher assim limitada sai desses limites nessas horas, finge que não tem problemas. Todas iguais" (RIBEIRO, 1999, p. 131-132).

A fala da narradora é marcada pela repetição anafórica do pronome adjetivo indefinido "toda". A série de generalizações feita por ela termina justamente com a asseveração de que todas as mulheres que não têm determinada prática sexual são iguais, fala que muito se aproxima de um discurso machista. A narradora parece considerar o seu próprio gênero como sendo homogêneo e, assim, passa por cima das diferenças e particularidades de cada indivíduo para afirmar a existência de desejos tipicamente femininos.

Outro tópico abordado é o da monogamia e adultério. O relato sobre sua relação com o irmão, que fora casado diversas vezes, a inspira a falar sobre esse assunto:

"Porque também acho esse negócio de cornidão o maior atraso de vida, ninguém é monógamo, nem homem nem mulher, só degenerado mesmo, masoca, deslibidado, doente da cabeça gravemente [...] Todo mundo é corno, mesmo que não seja, por uma mera questão conjuntural técnica" (RIBEIRO, 1999, p. 101-102).

Ainda que o enunciado da narradora comece com o uso do verbo "acho", que pertence, nesse 
caso, à modalidade epistêmica subjetiva, marcando uma crença pessoal, logo se segue uma série de generalizações iniciadas por "ninguém" e "todo mundo", que oscilam em direção a uma verdade universal (modalidade alética). A narradora faz referência novamente ao dualismo normal/anormal. Para ela, a fidelidade é reservada aos "doentes da cabeça", uma maneira radical de inverter os valores sociais. Existe no discurso da narradora, uma vontade de transgredir, de subverter. Ela vai assim contra todo um conjunto de valores morais vigentes: ela exalta o que é condenado socialmente (o adultério) e condena o que é exaltado (a fidelidade e a monogamia).

Como podemos constatar, através dos trechos analisados, o presente do indicativo é o tempo verbal privilegiado pela narradora em suas digressões argumentativas. Na obra Traité de l'Argumentation, é estudado o valor do presente e sua relação com a lei e a norma:

Le présent est le temps de la maxime, de la sentence, c'est-à-dire de ce qui est considéré comme toujours actuel, jamais périmé - c'est le présent qui semble par là avoir le rôle le plus équivoque : c'est lui qui exprime le mieux le normal dans son passage vers la norme. Dans une phrase comme "la femme aime à parler", on insiste sur le normal au point d'en faire un caractère général : on ne peut à première vue distinguer pareil énoncé de l'affirmation "l'homme est sujet à la mort". Si nous remplacions le présent par "on a constaté que la femme aimait à parler", la confusion avec le sens distributif serait beaucoup moins forte. On échapperait à la loi pour rester dans l'observation (PERELMAN ; OLBRECHTS-TYTECA, 1992, p. 118).

O uso do presente participa da passagem do normal ao normativo no romance. É importante enfatizar que, nas declarações da narradora, está implícito um sistema de valores, ou seja, ela define o que é certo ou errado, o que é bom e o que é ruim, o que é normal e anormal. A postura autoritária da narradora aproxima seu depoimento de discursos totalitários (o totalitarismo não aceita oposição), já que ela menospreza e desqualifica qualquer opinião ou postura contrária à sua.

CLB é uma grande sedutora e, em seu depoimento, ela se propõe seduzir o leitor, como ela seduziu os homens e mulheres que passaram pela sua vida. No entanto, para seduzir o leitor, a sua arma principal deixa de ser o corpo e passa a ser a palavra. E ela se revela uma hábil oradora, ao utilizar diversos recursos retóricos. João Ubaldo Ribeiro nos faz refletir, com essa personagem, sobre o poder do discurso. Sua narradora libertina, que a priori deveria privilegiar a liberdade individual, é autora de um discurso quase totalitário. Ao defender que o sexo é o centro de todas as coisas e ao definir o que é normal e o que é anormal, ela cria um discurso normativo e prescritivo, não deixando espaço para diferenças de opinião e para vontades individuais.

O discurso veiculado pela oradora é fascinante (e não é por acaso que o romance tenha virado uma peça teatral de sucesso), porque as ideias que ela veicula são extremamente subversivas, por vezes absurdas e polêmicas. Através do romance, o escritor explora o prazer que a transgressão e o escândalo propiciam. A escolha de Ubaldo Ribeiro por uma autora fictícia está muito provavelmente ligada ao desejo de criar uma figura complexa e distinta da sua, dando também uma maior impressão de autenticidade ao depoimento, o que potencializa ainda mais o seu caráter escandaloso. Ainda que tenha uma identidade à parte, a autora ficcional funciona como um tipo de alter ego subversivo do autor, que questiona, através da voz narrativa, diversas "verdades" sobre a vida e a sexualidade sem o véu da censura. Ao elaborar esse intricado jogo literário, João Ubaldo Ribeiro comprova sua capacidade de criar universos e narradores extraordinários e mostra que o gênero romanesco pode abarcar as mais diversas formas, jogos e tipos de discurso. $O$ autor prova também que a literatura é um espaço privilegiado, em que o artista pode questionar representações sociais, inverter valores, burlar convenções e imaginar diferentes realidades possíveis. 


\section{Referências}

ARISTÓTELES. Retórica (prefácio e introdução de Manuel Alexandre Júnior, tradução e notas de Manuel Alexandre Júnior, Paulo Farmhouse Alberto e Abel do Nascimento Pena). Lisboa: Centro de Filosofia da Universidade de Lisboa, Imprensa Nacional-Casa da Moeda, 2005.

PERELMAN, Chaïm ; OLBRECHTS-TYTECA, Lucie. Traité de l'argumentation: La nouvelle rhétorique [1988], Bruxelles : Éditions de l'Université de Bruxelles, 1992.
POTTIER Bernard, Sémantique générale, Paris, PUF, 1992, col. Linguistique nouvelle.

UBALDO RIBEIRO, João. A Casa dos Budas Ditosos. Rio de Janeiro: Editora Objetiva, 1999, col. Plenos Pecados.

\section{COMO CITAR ESSE ARTIGO}

DO CARMO SILVA, Leonardo Alexander. A argumentação e a configuração discursiva da certeza em A Casa dos Budas Ditosos. Signo, Santa Cruz do Sul, v. 42, n. 73, jan. 2017. ISSN 1982-2014. Disponível em: $<$ https://online.unisc.br/seer/index.php/signo/article/view/7695>. Acesso em: doi: http://dx.doi.org/10.17058/signo.v42i73.7695. 